Dhaka Univ. J. Sci. 64(2): 115-120, 2016 (July)

\title{
Interaction of Manganese(II) with Proton Pump Inhibitor at Different pH: A Cyclic Voltammetric Study

\author{
R. Biswas ${ }^{1}$, S. Islam ${ }^{1}$, M. S. Rahman ${ }^{1}$, M. A. Haque ${ }^{1}$, M. Abu Hasan', P. K. Bakshi ${ }^{1}$ and A. A. Shaikh ${ }^{1}$ * \\ ${ }^{1}$ Department of Chemistry, Dhaka University, Dhaka-1000, Bangladesh \\ ${ }^{2}$ Central Chemical Laboratory, Department of Narcotics Control, Gandaria, Dhaka- 1204, Bangladesh
}

(Received: 14 September 2015; Accepted: 18 May 2016)

\begin{abstract}
The electrochemistry of $\mathrm{Mn}^{2+}$ at different $\mathrm{pH}(3.5-4.5)$ in acetate buffer solution has been investigated, using cyclic voltammetric method at glassy carbon electrode (GCE). Cyclic voltammograms (CVs) of $\mathrm{Mn}^{2+}$ show two cathodic and an anodic peaks over the entire investigated pH. The CVs of $\mathrm{Mn}^{2+}$ has also been performed in presence of proton pump inhibitors (PPIs) such as omeprazole, pantoprazole, esomeprazole and rabeprazole to elucidate the interaction of $\mathrm{Mn}^{2+}$ with the PPIs in acetate buffer solution. At the studied $\mathrm{pH}$, a reasonably strong interaction was observed between $\mathrm{Mn}^{2+}$ and PPIs at different molar ratio of $\mathrm{Mn}^{2+}$ ion and PPIs. However, maximum interaction has been found at 1:2 molar ratio of $\mathrm{Mn}^{2+}$ and PPIs. This indicates the most suitable condition for the interaction between $\mathrm{Mn}^{2+}$ and PPIs. These results could allow insight into the interactions of metal ions with the PPIs.
\end{abstract}

Keywords: Transition metal ions, Proton pump inhibitors, Cyclic voltammetry, Glassy carbon electrode, Acetate buffer.

\section{Introduction}

A potential class of drugs with an excellent safety profile, proton pump inhibitors (PPIs) is widely used for the treatment of gastric-ulcer diseases ${ }^{1-4}$. PPIs are used comprehensively for the treatment of gastric acid-related disorders because they can produce a greater degree and longer duration of gastric acid suppression and thus, better healing rates, than histamine $\mathrm{H}_{2}$ receptor antagonists ${ }^{5-10}$. PPIs are the most probable inhibitors of gastric acid secretion with a prospective to increase intragastric $\mathrm{pH}$ by several units, as well as hydrogen ion concentration by several hundred to thousand fold ${ }^{11}$. PPIs are substituted benzimidazoles and are lipophilic weak bases that cross the parietal cell membrane and enter the acidic parietal cell canaliculus $^{12}$. In this acidic environment, the PPIs become protonated producing the activated sulphonamide from the drug that binds covalently with the $\mathrm{H}^{+}, \mathrm{K}^{+}$-ATPase enzyme resulting in irreversible inhibition of acid secretion by the proton pump. This enzyme is responsible for hydrogen ion secretion in exchange for potassium ions in the gastric lumen $^{13}$. As a result, PPIs can modify the bioavailability and absorption of essential vitamins and minerals both in the stomach and duodenum, which may also affect more distal absorption. PPIs act by irreversibly blocking the $\mathrm{H}^{+} / \mathrm{K}^{+}$ adenosine triphosphatase enzyme system of the gastric parietal cells ${ }^{14}$. Gastric nitrate rendering bacteria levels increase, as do carcinogenic nitrosamines in gastric juice. A $\mathrm{pH}$ of less than 3.8 allows gastric bacterial overgrowth ${ }^{15}$. The proton pump is the terminal stage in gastric acid secretion, being directly responsible for secreting $\mathrm{H}^{+}$ions into the gastric lumen, making it an ideal target for inhibiting acid secretion.

Several transition elements are important to the chemistry of living systems, the most familiar examples being iron, cobalt, copper, manganese and molybdenum. Most of the first row transition metals are important for enzymes ${ }^{16}$. They have one or both of two important properties: (i) some of them can be easily changed their oxidation state, (ii) acting as critical redox couples e.g. $\mathrm{Fe}(\mathrm{II}) / \mathrm{Fe}(\mathrm{III})$. Several have high charge density, making them good candidates for reaction centers. Iron is by far the most widespread and important transition metal that has a function in living systems; proteins containing iron participate in two main processes, oxygen transport and electron transfer reactions ${ }^{17}$. Several studies on the synthesis, characterization and applications of $\mathrm{Mn}^{2+}$-PPIs complexes has been reported elsewhere ${ }^{12,18,19}$.

The cyclic voltammetric study of various metal ions in presence of ligand has been investigated in our laboratory and reported in detail ${ }^{20,21}$. We have therefore, started a wide ranging electrochemical studies of metal complexes of PPIs using cyclic voltammetry. In the present paper we report a study of the electrochemical interaction of $\mathrm{Mn}^{2+}$ and PPIs such as omeprazole (Ome), pantoprazole (Pan), esomeprazole (Eso) and rabeprazole (Rab) in acetate buffer solution at various $\mathrm{pH}(3.5,4.0$ and 4.5$)$.

\section{Experimental}

\section{Materials and Methods}

Analar grade manganese(II) perchlorate $\left(\mathrm{Mn}\left(\mathrm{ClO}_{4}\right)_{2} \cdot \mathrm{xH}_{2} \mathrm{O}\right)$ has been purchased from Sigma-Aldrich and used without further purification. Analytical grade omeprazole, pantoprazole, esomeprazole and rabeprazole of SigmaAldrich were used in this study. For the preparation of acetate buffer solution, extra pure acetic acid (BDH, England) and sodium acetate (Merck Germany) were procured and used without further treatment. Sodium hydroxide (Merck, Germany) was used as it is available for maintaining the $\mathrm{pH}$ of the solution. All aqueous solutions were prepared in deionized water. The experiments were carried out at room temperature.

A three electrode electrochemical cell consisted of a working electrode (Glassy carbon electrode), a reference electrode $(\mathrm{Ag} / \mathrm{AgCl}($ satd. $\mathrm{KCl}))$ and a counter electrode $(\mathrm{Pt}$ wire) was used in this study. Cyclic voltammetric measurement was performed using computerized electrochemical workstation $(\mathrm{CH}$ Instruments Inc., USA; Model CHI 620D). 


\section{Preparation of various solutions}

The acetate buffer used in this study was prepared by mixing requisite volume of $0.1 \mathrm{M}$ sodium acetate $\left(\mathrm{CH}_{3} \mathrm{COONa} .3 \mathrm{H}_{2} \mathrm{O}\right)$ and $0.1 \mathrm{M}$ acetic acid $\left(\mathrm{CH}_{3} \mathrm{COOH}\right)$ solution. For the preparation of the $0.1 \mathrm{M} \mathrm{CH}_{3} \mathrm{COONa} 3 \mathrm{H}_{2} \mathrm{O}$ and $0.1 \mathrm{M} \mathrm{CH} \mathrm{CH}_{3} \mathrm{COOH}$ solutions, $50 \%$ ethanol-water was used as solvent. By the addition of $0.1 \mathrm{M}$ sodium hydroxide $(\mathrm{NaOH})$, the desired $\mathrm{pH}(3.5,4.0$ and 4.5$)$ was adjusted. Stock solution of $1.0 \mathrm{mM} \mathrm{Mn^{2+ }}$ was prepared with analytical grade hydrated manganese(II) perchlorate salt with acetate buffer solution. Four different concentrations (1.0 mM, 2.0 $\mathrm{mM}, 3.0 \mathrm{mM}$ and $4.0 \mathrm{mM}$ ) of omeprazole, pantoprazole sodium, esomeprazole magnesium and rabeprazole sodium solutions were prepared by using acetate buffer solution. The metal-ligand solutions for complexation reaction were prepared by mixing of identical amount (volume/volume) of metal and ligand solution to achieve 1:1, 1:2, 1:3 and 1:4 (metal-ligand) ratios at desired $\mathrm{pH}$.

Preparation of Working Electrode

In the present work glassy carbon electrode (GCE) was used as working electrode. This electrode preparation includes the polishing and conditioning of the electrode. At the beginning of each experiment, the working electrode was polished with alumina slurry (a few amount of alumina polishing powder of particle size 0.3 micron and a few drops of water) on the surface of water resistant polishing cloth. Then it was rinsed with plenty of de-ionized water and the whitish alumina was wiped off with a clean tissue paper. First of all, the cell was filled with desired volume of the experimental solution and the Teflon cap was placed on the cell. Then three electrodes were inserted in the solution.

\section{Results and Discussion}

Electrochemical redox behavior of $\mathrm{Mn}^{2+}$ in acetate buffer solution and their interaction with proton pump inhibitors (PPIs) such as omeprazole, pantoprazole, esomeprazole and rabeprazole were performed at GCE at various molar ratio and different scan rate. The effect of $\mathrm{pH}$ such as 3.5, 4.0 and 4.5 in acetate buffer solution was also examined in this study. The results are described below.

Cyclic voltammetry of $\mathrm{Mn}^{2+}$ in acetate buffer solution

Cyclic voltammetric study of $1.0 \mathrm{mM} \mathrm{Mn}^{2+}$ in acetate buffer solution at different $\mathrm{pH}$ values was investigated at GCE

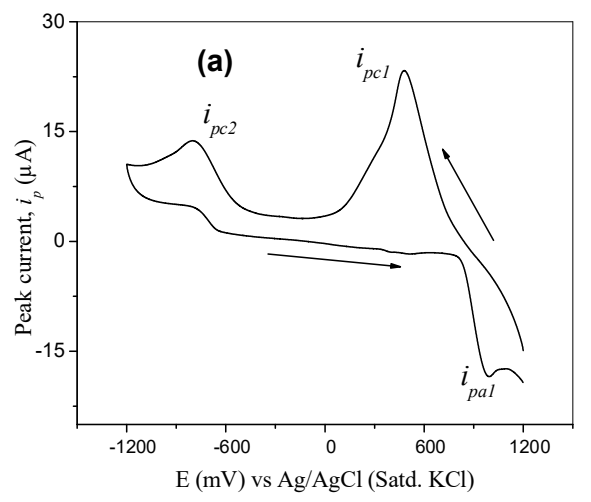

within the potential window of +1200 to $-1200 \mathrm{mV}$. Fig. 1(a), shows a $\mathrm{CV}$ of $1.0 \mathrm{mM} \mathrm{Mn}^{2+}$ in acetate buffer solution with scan rate of $100 \mathrm{mVs}^{-1}$ at $\mathrm{pH} 4.0$. In the forward scan two cathodic peak, $i_{p c l}$ at about $475.90 \mathrm{mV}$ and $i_{p c 2}$ at about $-798.4 \mathrm{mV}$ and in the reverse scan an anodic peak, $i_{p a l}$ at about $994.80 \mathrm{mV}$ were observed. The cathodic peaks result from the reduction of $\mathrm{Mn}^{2+}$ to $\mathrm{Mn}^{+}$and $\mathrm{Mn}^{+}$to $\mathrm{Mn}$, and the anodic peak is for the oxidation of $\mathrm{Mn}$ to $\mathrm{Mn}^{2+}$. The above result suggests that at $\mathrm{pH} 4.0 \mathrm{Mn}^{2+}$ undergoes single step two-electron transfer redox reaction which is in good agreement with the previous work [Radhi et al., 2010]. The possible mechanism of the redox reaction is as follows:

$$
\begin{aligned}
& \text { For reduction half-reaction } \\
& \mathrm{Mn}^{2+}+\mathrm{e} \rightarrow \mathrm{Mn}^{+} \\
& \mathrm{Mn}^{+}+\mathrm{e} \rightarrow \mathrm{Mn} \\
& \text { For oxidation half-reaction } \\
& \mathrm{Mn} \rightarrow \mathrm{Mn}^{2+}+2 \mathrm{e}
\end{aligned}
$$

Effect of scan rate: The effect of the scan rate on the electrochemical response of $\mathrm{Mn}^{2+}$ under the identical condition (1.0 $\mathrm{mM} \mathrm{Mn}^{2+}$ at $\left.\mathrm{pH} 4.0\right)$ was examined by taking the CVs of $\mathrm{Mn}^{2+}$ with scan rate of $25,75,100,125,175$ and $200 \mathrm{mVs}^{-1}$ as shown in Fig. 1(b). With the increasing of scan rate, the cathodic and anodic peak current increased. The observation suggests that the electrode process is diffusion controlled in acetate buffer medium. The ratio of the oxidation peak current and its corresponding reduction counterpart $i_{p a l} / i_{p c l}$ is about (1.074-1.376). It is found that the peak current ratio was increased with the increasing of scan rate. Also the peak potential separation, $\Delta \mathrm{E}_{\mathrm{p}}$ is in between $(357.10-570.40) \mathrm{mV}$. It is also increased with the variation of scan rate. These suggest that the redox couple $\mathrm{Mn}^{2+} / \mathrm{Mn}^{+}$follows a quasi-reversible reaction rather than a reversible reaction. Moreover, the shifting of the peak potential at various scan rates indicates quasi-reversibility of the redox process, which is also characterized by the shape and separation of the cathodic and anodic peak.

In addition to that the cathodic peaks are slightly shifted towards negative potential while the anodic peaks are moved a little towards positive potential with scan rate. This observation indicates that there is a tendency of the redox process shifted from quasi-reversible to irreversible direction.

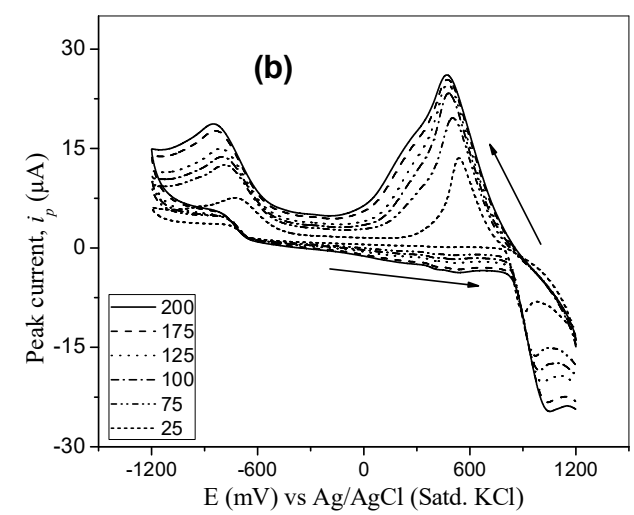

Fig. 1. (a) $\mathrm{CV}$ of $1.0 \mathrm{mM} \mathrm{Mn}^{2+}$ in acetate buffer solution at $\mathrm{pH} 4.0$ with scan rate of $100 \mathrm{mVs}^{-1}$ and (b) $\mathrm{CVs}_{\text {of }} 1.0 \mathrm{mM} \mathrm{Mn}^{2+}$ at various scan rate: 25 (semi das), 75 (dash dot dot), 100 (das dot), 125 (dot), 175 (dash) and 200 (solid) $\mathrm{mVs}^{-1}$ at GCE. 
In Fig. 2(a), it is apparent that the peak current for the electrochemical redox reaction of $\mathrm{Mn}^{2+}$ has linear relation with square root of scan rate. This observation is again in favor of the fact that the electrode process is diffusion controlled. The ratio of the oxidation peak current and its corresponding reduction counterpart has a linear relation with scan rate (Fig. 2(b)). Also the peak potential separation, $\Delta \mathrm{E}_{\mathrm{p}}$ is linearly increased with scan rate (Fig 2(c)). These results also suggest that the redox process is quasi-reversible reaction rather than a reversible reaction.
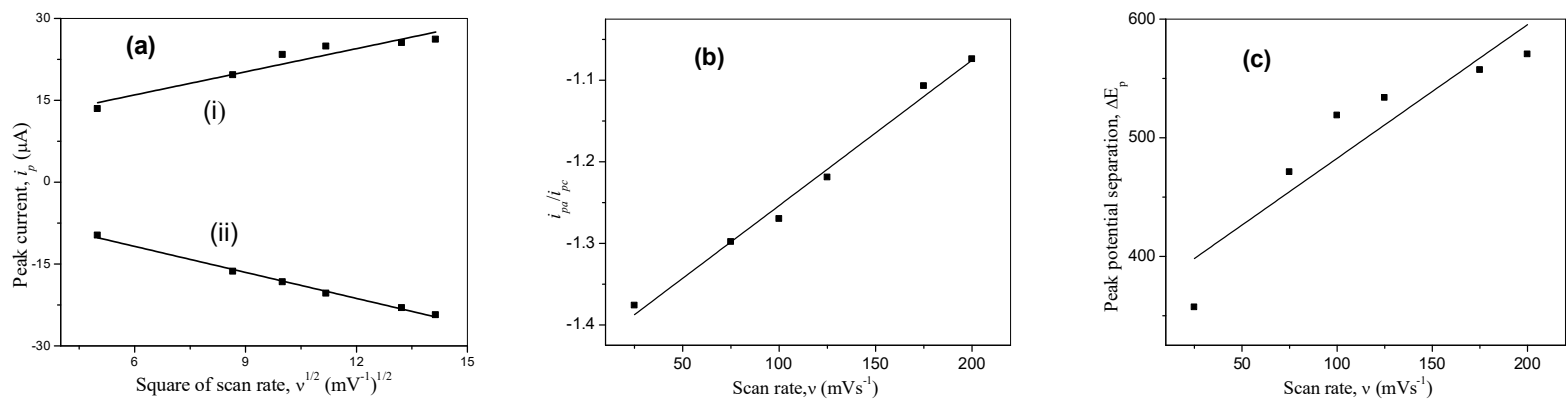

Fig. 2. (a) Plots of cathodic peak current (i) and anodic peak current (ii) as a function of square root of scan rate, (b) Peak current ratio $\left(i_{p a l} / i_{p c l}\right)$ dependence on scan rate and (c) A plot of peak potential separation with scan rate for $1.0 \mathrm{mM} \mathrm{Mn}^{2+}$ at $\mathrm{pH} 4.0$.

\section{Effect of $\mathrm{pH}$ on the cyclic voltammograms of $\mathrm{Mn}^{2+}$}

The effect of $\mathrm{pH}(\mathrm{pH} \mathrm{3.5,4.0}$ and 4.5) on the CVs of the redox reaction of $\mathrm{Mn}^{2+}$ in acetate buffer solution has been investigated as shown in Fig. 3. It is found that with the increase of $\mathrm{pH}$ intense cathodic peaks and distinguishable anodic peak are found. The data from the voltammograms are shown in Table 1.

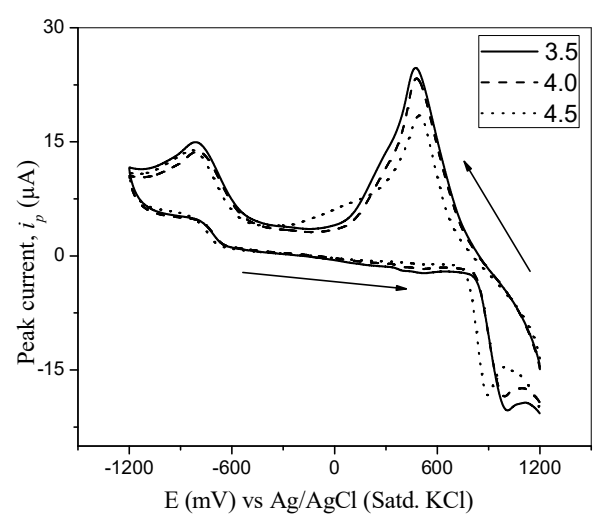

Fig. 3. $\mathrm{CVs}$ of $1.0 \mathrm{mM} \mathrm{Mn}{ }^{2+}$ in acetate buffer solution at $\mathrm{pH}$ 3.5 (solid), pH 4.0 (dash) and pH 4.5 (dot).

Table 1. Peak potential and peak current for the voltammograms obtained from $\mathrm{Mn}^{2+}$ at different $\mathrm{pH}$.

\begin{tabular}{|c|c|c|c|c|c|c|c|}
\hline $\mathrm{pH}$ & Peak & $i_{p} \mu \mathrm{A}$ & & Peak po & $\mathrm{ll}, \mathrm{E}_{\mathrm{p}} \mathrm{mV}$ & & PPS mV \\
\hline & $\overline{i_{p c l}}$ & $i_{p c 2}$ & $i_{p a l}(-)$ & $\mathrm{E}_{\mathrm{pc} 1}$ & $\mathrm{E}_{\mathrm{pc} 2}(-)$ & $\mathrm{E}_{\mathrm{pa} 1}$ & $\Delta \mathrm{E}=\mathrm{E}_{\mathrm{pa} 1}-\mathrm{E}_{\mathrm{pc} 1}$ \\
\hline 3.5 & 24.66 & 14.83 & 20.31 & 467.80 & 817.3 & 1005.40 & 537.60 \\
\hline 4.0 & 23.19 & 13.75 & 18.43 & 476.50 & 798.4 & 987.80 & 511.30 \\
\hline 4.5 & 18.49 & 13.84 & 18.22 & 491.20 & 829.8 & 893.80 & 893.80 \\
\hline
\end{tabular}

PPS $=$ Peak potential separation

Cyclic voltammetry of $\mathrm{Mn}^{2+}$ in presence of omeprazole (Ome)

The electrochemical studies of the interaction of $\mathrm{Mn}^{2+}$ with Ome in acetate buffer at $\mathrm{pH} 3.5,4.0$ and 4.5 have been carried out. The cyclic voltammograms recorded for $\mathrm{Mn}^{2+}$, and $\mathrm{Mn}^{2+}$ in presence of various molar concentrations of Ome (molar ratios of $\mathrm{Mn}^{2+} /$ Ome.; 1:1, 1:2, 1:3 and 1:4) are shown in Fig. 4. The voltammogram recorded for each ratio of $\mathrm{Mn}^{2+}$ and Ome, the peak current for both anodic and cathodic peaks decreased than those for free $\mathrm{Mn}^{2+}$. Moreover, it is apparently found that the anodic peak and the cathodic peak are disappeared for different ratio at aforementioned three $\mathrm{pH}$. The results suggest that there is an interaction between $\mathrm{Mn}^{2+}$ and Ome. It is obvious that a strong interaction occurs at 1:2 molar ratio of $\mathrm{Mn}^{2+}$ and Ome. However Ome showed small hump at acidic medium. 

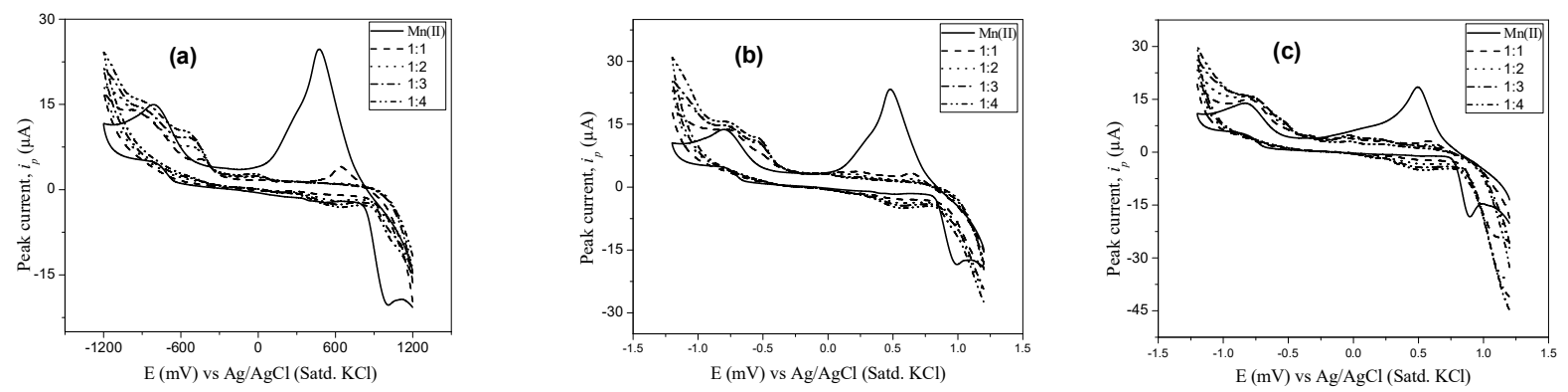

Fig. 4. $\mathrm{CVs}$ of $\mathrm{Mn}^{2+}$ (solid), and $\mathrm{Mn}^{2+} / \mathrm{Ome}$ with different ratio (i) 1:1 (dash), (ii) 1:2 (dot), (iii) 1:3 (dash dot), and (iv) 1:4 (dash dot dot) in acetate buffer solution at (a) $\mathrm{pH} 3.5$, (b) $\mathrm{pH} 4.0$ and (c) $\mathrm{pH} 4.5$.

Cyclic voltammetry of $\mathrm{Mn}^{2+}$ in presence of pantoprazole (Pan)

The electrochemical studies of the interaction of $\mathrm{Mn}^{2+}$ with Pan in acetate buffer at $\mathrm{pH} 3.5,4.0$ and 4.5 have been performed. The CVs recorded for $\mathrm{Mn}^{2+}$, and $\mathrm{Mn}^{2+}$ in presence of various molar concentrations of Pan (identical molar ratio as before) are shown in Fig. 5. The voltammogram recorded for each ratio of $\mathrm{Mn}^{2+}$ and Pan, the peak current for both anodic and cathodic peak decreased than those for free $\mathrm{Mn}^{2+}$. Additionally, it is apparently found that the anodic peak and the cathodic peak are disappeared for different ratio at $\mathrm{pH} 3.5, \mathrm{pH} 4.0$ and $\mathrm{pH} 4.5$. The results suggest that there is an interaction between $\mathrm{Mn}^{2+}$ and Pan and a strong interaction occurs at 1:2 molar ratio of $\mathrm{Mn}^{2+}$ and Pan.
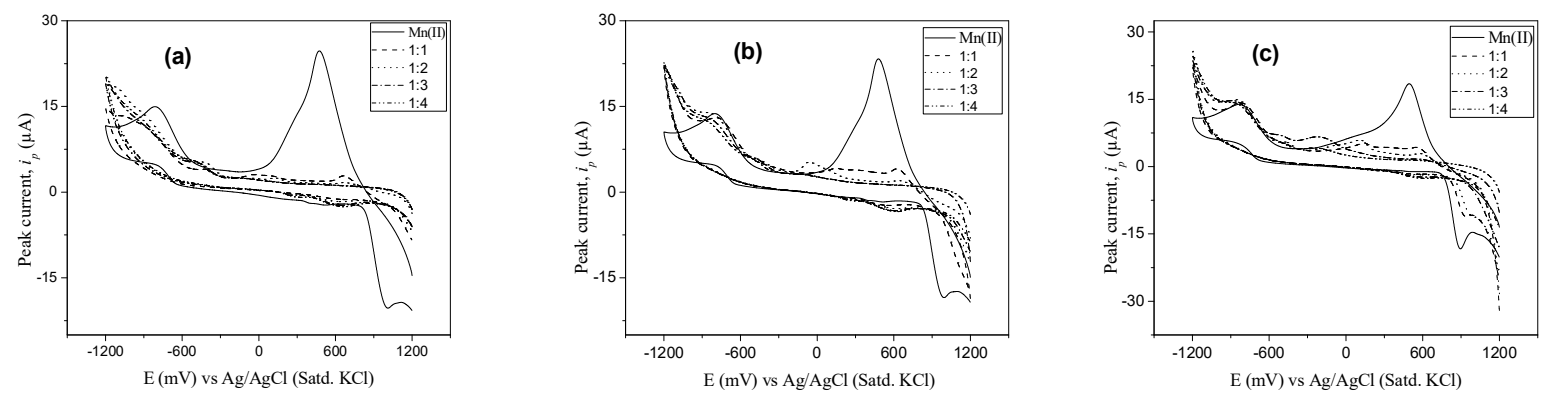

Fig. 5. CVs of $\mathrm{Mn}^{2+}$ (solid), and $\mathrm{Mn}^{2+} / \mathrm{Pan}$ with different ratio (i) 1:1 (dash), (ii) 1:2 (dot), (iii) 1:3 (dash dot), and (iv) 1:4 (dash dot dot) in acetate buffer solution at (a) $\mathrm{pH} 3.5$, (b) $\mathrm{pH} 4.0$ and (c) $\mathrm{pH} 4.5$.

Cyclic voltammetry of $\mathrm{Mn}^{2+}$ in presence of esomeprazole (Eso)

The electrochemical study of the interaction of $\mathrm{Mn}^{2+}$ with Eso in acetate buffer solution at $\mathrm{pH} 3.5,4.0$ and 4.5 has been carried out. The CVs recorded for $\mathrm{Mn}^{2+}$, and $\mathrm{Mn}^{2+}$ in presence of various molar concentrations of Eso (mentioned previously) are shown in Fig. 6. The voltammogram recorded for each ratio of $\mathrm{Mn}^{2+}$ and Eso, the peak current for both anodic and cathodic peak decreased than those for free $\mathrm{Mn}^{2+}$.
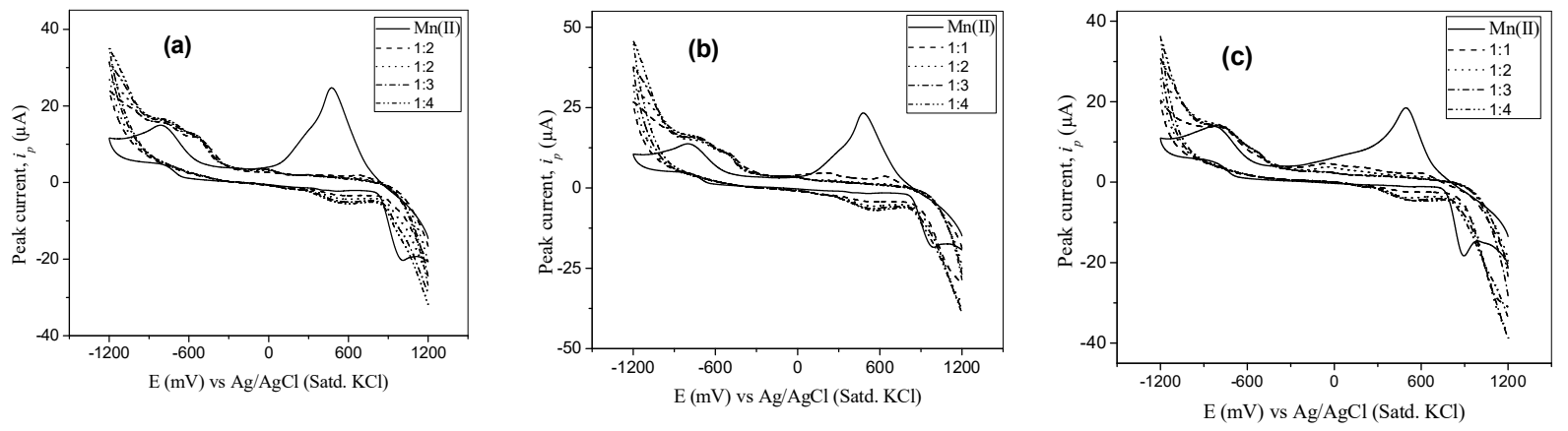

Fig. 6. CVs of $\mathrm{Mn}^{2+}$ (solid), and $\mathrm{Mn}^{2+} /$ Eso with different ratio (i) 1:1 (dash), (ii) 1:2 (dot), (iii) 1:3 (dash dot), and (iv) 1:4 (dash dot dot) in acetate buffer solution at (a) $\mathrm{pH} 3.5$, (b) $\mathrm{pH} 4.0$ and (c) $\mathrm{pH} 4.5$. 
In addition to that, it is apparently found that the anodic peak and the cathodic peak are disappeared for different ratio at aforementioned three $\mathrm{pH}$. The results suggest that there is an interaction between $\mathrm{Mn}^{2+}$ and Eso and it is obvious that a strong interaction occurs at 1:2 molar ratio of $\mathrm{Mn}^{2+}$ and Eso.

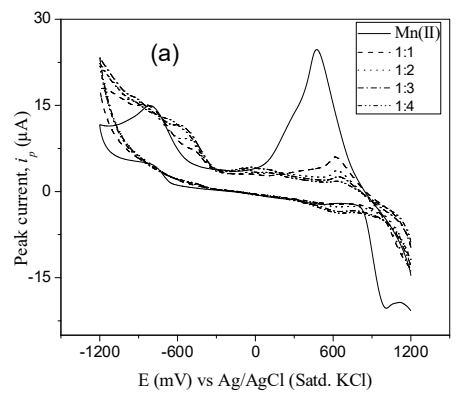

Cyclic voltammetry of $\mathrm{Mn}^{2+}$ in presence of rabeprazole (Rab)

The electrochemical study of the interaction of $\mathrm{Mn}^{2+}$ with $\mathrm{Rab}$ in acetate buffer at $\mathrm{pH} 3.5,4.0$ and 4.5 has been carried out. The recorded CVs for $\mathrm{Mn}^{2+}$ and $\mathrm{Mn}^{2+}$ in presence of various molar concentrations of $\mathrm{Rab}$ (molar ratios of $\mathrm{Mn}^{2+} / \mathrm{Rab} ; 1: 1$, $1: 2,1: 3$ and 1:4) are shown in Fig. 7.

Fig. 7. $\mathrm{CVs}$ of $\mathrm{Mn}^{2+}$ (solid), and $\mathrm{Mn}^{2+} / \mathrm{Rab}$ with different ratio (i) $1: 1$ (dash), (ii) 1:2 (dot), (iii) 1:3 (dash dot) and (iv) $1: 4$ (dash dot dot) in acetate buffer solution at (a) $\mathrm{pH} 3.5$, (b) $\mathrm{pH} 4.0$ and (c) $\mathrm{pH} 4.5$.

The voltammogram recorded for each ratio of $\mathrm{Mn}^{2+}$ and Rab, the peak current for both anodic and cathodic peak decreased compared to those for free $\mathrm{Mn}^{2+}$. Moreover, it is apparently found that the anodic peak and the cathodic peak are disappeared for different ratio at aforementioned three $\mathrm{pH}$. The results suggest that there is an interaction between $\mathrm{Mn}^{2+}$ and Rab. From the Fig. 7, it is obvious that a strong interaction occurs at 1:2 molar ratio of $\mathrm{Mn}^{2+}$ and $\mathrm{Rab}$.

\section{Conclusions}

The interactions between $\mathrm{Mn}^{2+}$ and the proton pump inhibitors (PPIs) such as omeprazole, pantoprazole, esomeprazole and rabeprazole in acetate buffer solution has been investigated at various $\mathrm{pH}(3.5,4.0$ and 4.5$)$ employing cyclic voltammetric technique at glassy carbon electrode. The CV of $\mathrm{Mn}^{2+}$ shows two cathodic peaks and an intense anodic peak in the studied $\mathrm{pH}$. The peak potential separation and peak current ratio revealed that the redox process follows quasi-reversible reaction path. The effect of $\mathrm{pH}$ on the redox behavior of $\mathrm{Mn}^{2+}$ showed that with the increase of solution $\mathrm{pH}$, the peak current increased. In presence of omeprazole for $\mathrm{Mn}^{2+}$, the anodic peak current decreased compared to solely $\mathrm{Mn}^{2+}$. However, the cathodic peak was completely disappeared. Moreover, anodic peak shifted significantly towards positive direction. This is an indication of strong interaction of $\mathrm{Mn}^{2+}$ and omeprazole. The maximum interaction is found at 1:2 molar ratio of $\mathrm{Mn}^{2+}$ and omeprazole at studied $\mathrm{pH}$. Almost identical behavior was observed for the electrochemical interaction of $\mathrm{Mn}^{2+}$ and other PPIs. The electrochemical study of the interactions between metal ions and PPIs would provide important information for the technological application of PPIs in human body.

\section{Acknowledgement}

The authors are grateful to the Ministry of Education of Bangladesh for the financial support to complete the work.

\section{References}

1. Richardson, P., J. Christopher and W. A. Stack., 1998. Proton pump inhibitors. Drugs 56:307-335

2. Fock, K. M., T. L. Ang, L. C. Bee and E. J. D. Lee., 2008. Proton pump inhibitors. Clin. Pharmacokinet. 47:1-6.

3. Sachs, G., J. M. Shin and C. W. Howden., 2006. Review article: The clinical pharmacology of proton pump inhibitors. Alimentary Pharmacol. Therapeut. 23:2-8.

4. Christopher, P., M. M. Farrella and D. S. Rudolpha, et al. 2011. Proton Pump Inhibitors Interfere With Zinc Absorption and Zinc Body Stores. Gastroenterol. Res. 4: 243-251.

5. Blume, H., F. Donath, A. Warnke and B. S. Schug., 2006. Pharmacokinetic Drug Interaction Profiles of Proton Pump Inhibitors. Drug Safety 29: 769-784.

6. Horn, J., 2000. The proton-pump inhibitors: similarities and differences. Clin Ther. 22:266-80.

7. Welage, L. S. and R. R. Berardi., 2000. Evaluation of omeprazole, lansoprazole, pantoprazole, and rabeprazole in the treatment of acid-related diseases. J Am Pharm Assoc. 40: $52-62$.

8. Gerson, L. B. and G. Triadafilopoulos., 2001. Proton pump inhibitors and their drug interactions: an evidence-based approach. Eur J Gastroenterol Hepatol. 13: 611-6.

9. Sibbing, D. and A. Kastrati, 2009. Risk of combining PPIs with thienopyridines: fact or fiction? The Lancet. 374: 952954.

10. Stone, G. W., 2009. Ischaemia versus bleeding: the art of clinical decision-making. The Lancet. 373: 695-696.

11. McColl, K. E., 2009. Effect of proton pump inhibitors on vitamins and iron. Am. J. Gastroenterol. 104: S5-S9.

12. Malik, S., S. Das and B. Jain., 2010. First-row transition metal complexes of omeprazole as anti-ulcerative drugs. Indo. J. Chem. 10: 382-389.

13. Sheen, E. and G. Triadafilopoulos, 2011. Adverse effects of long-term proton pump inhibitor therapy. Dig. Dis. Sci. 56: 931-950. 
14. Zajac, P., A. Holbrook, M. E. Super and M. Vogt., 2013. An overview: Current clinical guidelines for the evaluation, diagnosis, treatment, and management of dyspepsia. Osteopath. Family Physician. 5: 79-85.

15. Theisen, J., D. Nehra, D. Citron, J. Johansson and J. A. Hagen, et al. 2000. Suppression of gastric acid secretion in patients with gastroesophageal reflux disease results in gastric bacterial overgrowth and deconjugation of bile acids. $J$ Gastrointest Surg. 4: 50-54.

16. Dlouhy, A. C. and C. E. Outten., 2013. Chapter 8. The Iron Metallome in Eukaryotic Organism. In L. Banci Ed. Metallomics and the Cell. Metal Ions in Life Sciences 12. Spinger electronic book.

17. Finney, L. and T. O'Halloran., 2003. Transition metal speciation in the cell: insights from the chemistry of metal ion receptors. Science 300: 5621.
18. Malik, S., S. Das, A. Singh and L. Mitu., 2012. 3D-metal complexes derived from proton pump inhibitors-synthesis, characterization and biological studies. E-J. Chem. 9: 1919-1928.

19. Mohamed, G. G., F. A. Nour El-Dien, S. M. Khalil and A. S. Mohammad., 2009. Metal complexes of omeprazole. Preparation, spectroscopic and thermal characterization and biological activity. J. Coord. Chem. 62: 645-654.

20. Shaikh, A. A., S. N. Afzal, M. Q. Ehsan and A. H. Khan., 2005. Electrochemical study on redox reaction of iodine and bromine in presence of benzoylacetone at carbon electrodes. J. Saudi. Chem. Soc. 9: 279-286

21. Shaikh, A. A., M. Begum, A. H. Khan and M. Q. Ehsan., 2006. Cyclic voltammetric studies of the redox behavior of Iron(III)-vitamin $\mathrm{B}_{6}$ complex at carbon paste electrode. Russ. J. Electrochem. 42: 620-625. 
